\title{
Evaluation of candidate genes for familial brachydactyly
}

\author{
Joan M Mastrobattista, Pascal Dollé, Susan H Blanton, Hope Northrup
}

\begin{abstract}
Type A1 brachydactyly in humans is a recognisable syndrome characterised by shortening of the middle phalanx of all digits with occasional fusion of the middle and terminal phalanges. The purpose of this study was to evaluate candidate genes for type A1 brachydactyly in two families with multiple affected members. Several classes of genes have been implicated in the control of distal limb development including homeobox containing genes (MSX1, MSX2), some members of the homeobox gene family, and genes encoding growth factors of the FGF, TGF, and PDGF families. Homeobox (Hox) genes are a family of developmental control genes activated early in embryogenesis that encode positional information along the anterior-posterior body axis and specify distinct spatial domains within developing limbs. Growth factor genes can regulate the proliferation and differentiation of various embryonic structures including limb buds and have been shown to influence Hox gene expression. Candidate genes HOXD, MSX1, MSX2, FGF1 , and FGF-2 were excluded in one family. The brachydactyly type A1 gene or locus was not found in either of the two families studied.
\end{abstract}

( $($ Med Genet 1995;32:851-854)

Congenital hand anomalies have an estimated prevalence at birth of approximately $5 / 1000 .^{1}$ One type of congenital hand anomaly is brachydactyly which Bell classified into seven types: A1, A2, A3, B, C, D, and $\mathrm{E}^{2}$ In the type A brachydactylies, variable abnormalities of the middle phalanges are observed. Type A1 brachydactyly (Farabee type, MIM 112500) is an autosomal dominant condition ${ }^{2}$ for which Bell's criteria are: shortening of the middle phalanx of all digits (both hands and feet), shortening of the proximal phalanges of the first digit, and occasional fusion between the middle and terminal phalanges. Variable expressivity is common.

Two classes of homeobox genes have been implicated in the control of distal limb development, namely some of the HOXD and HOXA genes (previously called HOX4 and HOX 1$)^{3-5}$ as well as the MSX1 and MSX2 genes (previously called HOX7 and HOX8, although these genes do not structurally belong to the Hox gene family). ${ }^{67}$ Hox genes are a family of genes which are clustered in four complexes (HOXA, B, C, D) and encode positional information along the anterior-posterior body axis and the limb axes. ${ }^{3589}$ These genes have been conserved in evolution from invertebrates to humans. ${ }^{3910} \mathrm{~A}$ loss of function mutation of the murine Hoxd-13 gene through gene targeting resulted in mice with tetramelic skeletal abnormalities. ${ }^{11}$ The defects, which were restricted to the distal extremities of the limbs (the forefeet and hindfeet), included the reduction or absence of some skeletal elements as well as skeletal fusions. Muscles, tendons, and skin were apparently not affected. In these respects, the defects found in the murine Hoxd13 mutation are similar to those found in human type A1 brachydactyly.

Another group of candidate genes are certain growth factor genes which are specifically expressed during limb development and can have stimulatory or inhibitory effects on limb growth and patterning. ${ }^{12-15}$ Growth factors have also been shown to influence Hox gene expression in in vitro experiments. ${ }^{3}$ Growth factor genes of interest include: fibroblast growth factor (FGF) $-1,-2,-4,{ }^{12-15}$ transforming growth factoralpha (TGF- $\alpha),{ }^{16}$ platelet derived growth factor-alpha (PDGF- $\alpha),{ }^{17}$ and platelet derived growth factor-beta (PDGF- $\beta$ ). ${ }^{1618}$ Many of these genes have been cloned and polymorphisms described.

The purpose of this study was to evaluate candidate genes for type Al brachydactyly in humans. The similarities between the human type A1 brachydactyly and the murine Hoxd13 mutation $^{311}$ suggest that the human disease may result from a mutation in the HOXD complex. We therefore analysed the HOXD locus as well as the MSX1 and MSX2 genes by sequencing gel electrophoresis for linkage to type Al brachydactyly in two families containing a total of 11 affected persons (figure). We also evaluated growth factor genes FGF-1, FGF-2, PDGF- $\alpha$, PDGF- $\beta$, and TGF- $\alpha$ by sequencing gel electrophoresis or Southern blotting.

Patients, materials, and methods

Two families diagnosed with type A1 brachydactyly were ascertained through a review of medical records at the Shriner's Hospital for Crippled Children-Houston Unit and the University of Texas Houston Medical Genetics clinic. One family was of Scandinavian descent (five affected members) and the other of Mexican descent (six affected members). The institutional review boards at both institutions approved the protocol and written informed consent was obtained from both families. 


\section{I}

II

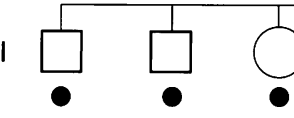

III

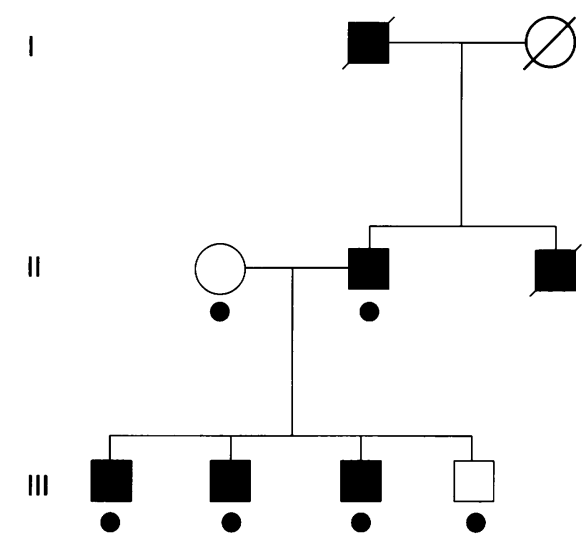

Family 1 (top) and family 2 (bottom) are depicted. The filled circles beneath the pedigree symbols denote people enrolled in the study.

Of the 17 participants in the study, 13 were examined by one of the authors (JM or HN). The remaining four were examined by the family's private physician who provided specific information. The thorough examination of each participant's hands and feet included: hand length, middle finger length, evaluation of palmar creasing patterns, and shoe size. The proband in each family underwent radiological evaluation of their hands and feet. Persons were regarded as affected with type Al brachydactyly if Bell's criteria were fulfilled. Pedigrees of the families are shown in the figure.

Genomic DNA was extracted from fresh, anticoagulated blood samples from indicated members of the affected families (figure).${ }^{19}$ Five candidate loci (HOXD, MSX1, MSX2, FGF1 , PDGF- $\beta$ ) contained dinucleotide repeat polymorphisms which were tested in the families.

Standard polymerase chain reactions (PCR), as described by Weber and May, ${ }^{20}$ were modified and carried out in $20 \mu \mathrm{l}$ volumes which contained $20 \mathrm{ng}$ genomic DNA, $100 \mathrm{ng}$ each of oligonucleotide primer, $200 \mu \mathrm{mol} / 1$ each of dGTP, dCTP, dTTP, dATP, $0.08 \mu \mathrm{l} \alpha \mathrm{P} 32$ $\mathrm{dCTP}$ at $3000 \mathrm{Ci} / \mathrm{mmol}, 2.0 \mu \mathrm{l}$ of $10 \times$ buffer $(100 \mathrm{mmol} / \mathrm{l}$ Tris- $\mathrm{HCl}, 15 \mathrm{mmol} / \mathrm{l} \mathrm{MgCl}$, $500 \mathrm{mmol} / 1 \mathrm{KCl}, \mathrm{pH} 8.3$ at $20^{\circ} \mathrm{C}$ ), 0.25 units Taq (Perkin-Elmer Cetus, Norwalk, CT).
Samples were overlaid with mineral oil and processed through 30 temperature cycles consisting of denaturation, annealing, and elongation (temperature cycles varied depending on the primer pair involved). Aliquots of amplified DNA were mixed with a stop solution containing formamide and electrophoresed on standard polyacrylamide sequencing gels. Gels were processed, dried, and exposed to autoradiography for 24 to 48 hours at room temperature. A standard $M-13 \mathrm{mp} 18$ sequencing ladder was used to compare DNA banding sizes. ${ }^{20}$ Primer pairs from within $\mathrm{HOXD},{ }^{21}$ MSX1, ${ }^{22}$ MSX2, ${ }^{23}$ FGF-1, ${ }^{24}$ and PDGF- $\beta^{25}$ were used in the experiments.

One candidate gene, TGF $-\alpha,{ }^{26}$ contained a TaqI site detectable on an agarose gel stained with ethidium bromide after PCR amplification. A DNA molecular weight marker was used as a standard and specific fragments were identified.

Two candidate genes, FGF-2 and PDGF- $\alpha$, contained restriction fragment length polymorphisms (RFLPs) located in introns. FGF2 contains a HindIII site polymorphism. A pair of synthetic oligonucleotides, (TCAAGCTACAACTTCAAGCA) and (AGAAGCCAGTAATCTTCCATC) were designed to amplify the second exon and used as a probe in the experiment. ${ }^{27}$ PDGF- $\alpha$ contains a StyI polymorphism $^{28}$ which was detected by Southern blotting and probing with a $1.7 \mathrm{~kb}$ PDGF- $\alpha$ probe (clone-IB657; ATCC number-86274). ${ }^{19}$

Linkage analysis was performed using the MLINK program of the LINKAGE package (version 5.03) ${ }^{29}$ Lod scores between the disease and each marker locus were generated for each family and then summed over both families. ${ }^{30}$ The two families had the potential of generating a maximum total lod score of 3.01 of which family 1 contributed $2 \cdot 107$ and family 2 contributed 0.903 . Markers within the various genes were studied for inclusion or exclusion as candidate genes; therefore, a lod score of -2 eliminated the gene as a candidate.

\section{Results}

The families analysed contained 11 persons affected with type Al brachydactyly (figure). Two point lod scores between type A1 brachydactyly and the candidate genes are presented in the table. HOXD was informative in both families, and combined lod scores at $\theta=$ 0.05 were less than -2.0 ; however, family 2 was informative without any recombination yielding a lod score of $0 \cdot 9$. Lod scores in family 1 were negative. Therefore HOXD was eliminated as a candidate locus in family 1 but not in family 2. MSX1 was informative only in family 1 and was eliminated as a candidate gene with a lod score of -3.90 at $\theta=0.01$. MSX2 was informative only in family 2 and was eliminated as a candidate gene with a lod score of $-2 \cdot 10$ at $\theta=0 \cdot 001$. FGF-1 was informative in both families and excluded as a candidate gene with a lod score of $-2 \cdot 10$ at a $\theta$ of $0 \cdot 05$. FGF-2 was informative only in family 1 and was eliminated as a candidate gene with a lod score of $-2 \cdot 10$ at $\theta=0 \cdot 001$. Other can- 
Lod scores and number of informative families for each locus. PDGF-, , PDGF- $\beta$, and $T G F-x$ were uninformative in both families.

\begin{tabular}{|c|c|c|c|c|c|c|c|c|c|}
\hline \multirow{2}{*}{ Locus } & \multirow{2}{*}{$\begin{array}{l}\text { Family } \\
\text { No }\end{array}$} & \multicolumn{8}{|c|}{ Recombination fraction $(\theta)$} \\
\hline & & 0.00 & 0.001 & 0.01 & 0.05 & $0 \cdot 10$ & $0 \cdot 15$ & $0 \cdot 20$ & $0 \cdot 30$ \\
\hline \multirow[t]{2}{*}{ HOXD } & $\begin{array}{l}1 \\
2\end{array}$ & $\begin{array}{r}-x \\
0.90\end{array}$ & $\begin{array}{r}-9.90 \\
0.90\end{array}$ & $\begin{array}{r}-5.91 \\
0.89\end{array}$ & $\begin{array}{r}-3.16 \\
0.81\end{array}$ & $\begin{array}{r}-2.03 \\
0.72\end{array}$ & $\begin{array}{r}-1.40 \\
0.62\end{array}$ & $\begin{array}{r}-1.00 \\
0.57\end{array}$ & $\begin{array}{r}-0.45 \\
0.30\end{array}$ \\
\hline & $1 \& 2$ & $-x$ & $-9 \cdot 00$ & -5.02 & $-2 \cdot 35$ & -1.31 & -0.78 & -0.43 & -0.15 \\
\hline HOXMSX1 & 1 & $-x$ & $-6 \cdot 90$ & $-3 \cdot 91$ & -1.89 & $-1 \cdot 08$ & -0.65 & -0.38 & -0.08 \\
\hline HOXMSX 2 & 2 & $-x$ & $-2 \cdot 10$ & $-1 \cdot 11$ & $-0 \cdot 46$ & $-0 \cdot 23$ & $-0 \cdot 12$ & -0.06 & -0.01 \\
\hline \multirow[t]{3}{*}{ FGF-1 } & 1 & $-x$ & $-5 \cdot 40$ & $-3 \cdot 40$ & $-2 \cdot 00$ & $-1 \cdot 40$ & -1.05 & -0.80 & -0.44 \\
\hline & & $-0 \cdot 17$ & $-0 \cdot 17$ & $-0 \cdot 15$ & $-0 \cdot 10$ & -0.06 & $-0 \cdot 04$ & -0.02 & 0.00 \\
\hline & $1 \& 2$ & $-x$ & $-5 \cdot 57$ & -3.55 & $-2 \cdot 10$ & $-1 \cdot 46$ & -1.09 & -0.82 & -0.44 \\
\hline FGF-2 & 1 & $-x$ & $-2 \cdot 10$ & $-1 \cdot 11$ & $-0 \cdot 44$ & $-0 \cdot 19$ & -0.06 & 0.01 & 0.07 \\
\hline
\end{tabular}

Lod scores are recorded in all cases where informative by family number. When both families are informative, combined scores are calculated.

didate genes tested which were uninformative in both families were PDGF- $\alpha$, PDGF- $\beta$, and TGF- $x$.

\section{Discussion}

DNA from members of two families (17 people) affected with brachydactyly type A1 was tested for linkage to eight candidate genes to determine whether one might be the gene responsible for the condition in these two families. While the number and size of the families were small, we had the capability either to include linkage with a maximum lod score of 3.01 as calculated by MLINK or exclude linkage with a lod score of $<-2$. With only two families, we were unable to detect genetic heterogeneity.

The homeobox genes and growth factor genes were among the most promising candidate genes available for the following reasons. Earlier studies on mutations in Drosophila and Xenopus embryos strongly suggested that members of the FGF and TGF families may provide signals required for the early establishment of the body plan. ${ }^{3}$ Some growth factors belonging to the same families are specifically expressed in the developing vertebrate limb and are able to interfere with limb growth and patterning under experimental conditions. ${ }^{314}$ Several HOXA, C, and D genes display specific temporal and spatial expression domains in developing limbs. ${ }^{45}$ Furthermore, a Hoxd-13 targeted mutation in the mouse showed a phenotype somewhat analogous to human brachydactyly type A1. ${ }^{11}$ The MSX1 and MSX2 homeobox genes are believed to be involved in epithelium/mesenchyme interactions which are critical for limb growth and patterning. ${ }^{67}$

The brachydactyly type Al gene was not found among the candidate genes tested. Overall, five loci (HOXD, MSX1, MSX2, FGF-1, and FGF-2) were excluded in either one or both families. Candidacy of HOXD remains, however, equivocal as it was weakly linked in one family but not the other. Future objectives are to ascertain additional families and to test these and other candidate genes.

Future areas of study include the evaluation of additional Hox genes, such as those belonging to the HOXA and HOXC complexes, in brachydactyly type A1 patients or in other human congenital limb abnormalities. Recent investigations have shown that a member of the TGF- $\beta$ superfamily (the $G d f-5$ gene) is responsible for the mouse brachypodism mutation, whose phenotype is a reduction in the length and number of the long bones of the limb. ${ }^{31}$ In addition, the fibroblast growth factor4 protein (FGF-4) has been shown to stimulate proliferation of cells in distal limb mesenchyme and cause limb outgrowth while bone morphogenetic protein-2 (BMP-2) can counteract this growth promoting effect. ${ }^{14}$ Very recently, the FGF-8 gene was also shown to be specifically expressed in developing limbs. ${ }^{32}$ All of these genes represent additional candidates to investigate. The endeavour to find candidate genes should help unravel the link between altered gene regulation and the perturbation of a developmental process such as limb patterning.

We wish to thank Jacqueline $\mathrm{T}$ Hecht, $\mathrm{PhD}$ and Jonathan $\mathrm{D}$ Stein, BS for supplying several primers used in this project. We also wish to thank the families involved in the study for their participation and the Shriners Hospital for Crippled ChildrenHouston Unit.

1 Zguricas J, Snijders PJLM, Hovius SER, Heutink P, Oostra BA, Lindhout D. Phenotypic analysis of triphalangeal $\mathrm{BA}$, Lindhout $\mathrm{D}$. Phenotypic analysis of triphalangeal thumb and associ.

2 Temtamy S, McKusick V. Brachydactyly as an isolated malformation. In: Bergsma D, Mudge JR, Paul NW Greene SC, eds. The genetics of hand malformations. Vo 14(3). New York: A R Liss, 1978:187-226.

3 Redline RW, Neish A, Holmes LB, Collins T. Biology of disease-homeobox genes and congenital malformations. Lab Invest 1992;66:659-70.

4 Dollé P, Izpisua-Belmonte JC, Boncinelli E, Duboule D. The Hox -4.8 gene is localized at the $5^{\prime}$ extremity of the Hox-4 complex and is expressed in most posterior parts of the body during development. Mech Dev 1991;36:3-13.

5 Duboule D. The vertebrate limb: a model system to study the hox/HOM gene network during development and evolution. BioEssays 1992;14:375-84

6 Taylor-Zimmerman GP, Muneoka K. Embryonic limb bud regulation correlates with $m s x-1$ expression. Proceedings of the fourth international conference on limb development and the fourth international conference on $\operatorname{limb}$ develo
regeneration. Asilomar, CA, July 1992: A846.

7 Coelho CND, Sumoy L, Rogina B, Upholt WB, Kosher RA. Roles of the chicken homeobox-containing genes ghox-8, ghox-7, and ghox-4.6 in pattern formation during limb development. In: Fallon JF, Goetinck PF, Kelley $\mathrm{RO}$, Stocum DL, eds. Limb development and regeneration, Part A. 4th ed. New York: Wiley-Liss, 1993:61-70.

8 Thompson MW, McInnes RR, Willard HF. The human gene map: gene mapping and linkage analysis. In: Thompson and Thompson genetics in medicine. 5th ed. Philadelphia: W B Saunders, 1991:167-99.

9 Watson JD, Gilman M, Witkowski J, Zoller M, eds. Genes control development of drosophila. In: Recombinant $D N A$ 2nd ed. New York: W H Freeman, 1992:389-407.

10 Acampora D, D'Esposito M, Faiella A, et al. The human HOX gene family. Nucleic Acids Res 1989;17:10385-402.

11 Dolle $\mathrm{P}$, Dierich A, LeMeur M, et al. Disruption of the Hoxd-13 gene induces localized heterochromy leading to Hoxd-13 gene induces localized heterochromy le
mice with neotenic limbs. Cell 1993;75:431-41.

12 Anderson R, Landry $M$, Muneoka $K$. In vitro maintenance of posterior (ZPA) signalling in mouse limb bud cells. In Fallon JF, Goetinck PF, Kelley RO, Stocum DL, eds. Limb development and regeneration. Part A. 4th ed. New York: Wiley-Liss, 1993:371-80.

13 Reginelli AD, Anderson R, Muneoka K. ZPA signaling, $f g f$ 2 and hox-d gene expression. Proceedings of the fourth international conference on limb development and regeneration. Asilomar, CA, July 1992:A849.

14 Niswander L, Martin GR. Fgf-4 and bmp-2 have opposite effects on limb growth. Nature 1993;361:68-71.

15 Baird A, Klagsbrun $M$. The fibroblast growth factor family: an overview. Ann N Y Acad Sci 1991;638:xi-ii.

16 Adamson ED. Oncogenes in development. Development 1987;99:449-71.

17 Carrington JL, Potts JD. Detection of messenger RNA for a platelet-derived growth factor $(P D G F) x$ receptor-like molecule in chicken limb buds using the polymerase chain reaction (PCR). In: Fallon JF, Goetinck PF, Kelley RO reaction (PCR). In: Fallon JF, Goetinck PF, Kelley RO, Stocum DL, eds. Limb development and regenerat
B. 4th ed. New York: Wiley-Liss, 1993:667-72.

18 Chen P, Carrington JL, Paralkar VM, Pierce GF, Reddi AH. Chick limb bud mesodermal cell chondrogenesis: inhibition by isoforms of platelet-derived growth factor inhibition by isoforms of platelet-derived growth factor and reversal by recombinant bone
Exp Cell Res 1922;200:110-17.

19 Martin AO, Northrup H, Ledbetter DH, et al. Prenatal detection of 46,XY,rec(5), dup q,inv(5)(p13q33) using DNA analysis, flow cytometry, and in situ hybridization to supplement classical cytogenetic analysis. $\mathrm{Am} \mathcal{f} \mathrm{Med}$ Genet 1988;31:643-54

20 Weber JL, May PE. Abundant class of human DNA poly- 
morphisms which can be typed using the polymerase chain reaction. Am f Hum Genet 1989;44:388-96.

21 Rosen DR, Brown RH Jr. Dinucleotide repeat polymorphism in the HOX4E locus. Hum Mol Genet 1993;2: 617.

22 Padanilam BJ, Stadler HS, Mills KA, et al. Characterization of the human $H O X 7 \mathrm{cDNA}$ and identification of polymorphic markers. Hum Mol Genet 1992;1:407-10.

23 Jabs EW, Muller U, Li X, et al. A mutation in the homeodomain of the human $M S X 2$ gene in a family affected with autosomal dominant craniosynostosis. Cell 1993;75: 443-50.

24 Li X, Jaye M, Crumley G, et al. Dinucleotide repeat polymorphism in the human fibroblast growth factor acidic (FGFA) gene on chromosome 5. Hum Mol Genet 1992;1: 216.

25 Patterson H, Mitchell PJ, Cooper CS, Stratton MR. Dinucleotide repeat polymorphisms at the SIS locus. Nucleic Acids Res 1990;18:5917.

26 Qian JF, Feingold J, Stoll C, May E. Transforming growth factor-alpha: characterization of the BamHI, RsaI and
TaqI polymorphic regions. Am f Hum Genet 1993;53:

27 Abraham JA, Whang JL, Tumolo A, et al. Human basic fibroblast growth factor: nucleotide sequence and genomic organization. EMBO f 1986;5:2523-8.

28 Ferns GAA, Ross R. StyI RFLP of the human platelet derived growth factor (PDGF) A-chain gene. Nucleic Acids Res 1990;18:208.

29 Lathrop GM, Lalouel JM, Julier C, Ott J. Strategies for multilocus linkage analysis in humans. Proc Natl Acad Sci USA 1984;81:3443-6.

30 Ott J. Analysis of human genetic linkage. Baltimore: Johns Hopkins University Press, 1985.

31 Storm EE, Huynh TV, Copeland NG, Jenkins NA, Kingsley $\mathrm{DM}$, Lee S. Limb alterations in brachypodism in mice due to mutations in a new member of the TGF $\beta$-superfamily. to mutations in a new me

32 Crossley PH, Martin GR. The mouse Fgf 8 gene encodes a family of polypeptides and is expressed in regions that direct outgrowth and patterning in the developing embryo. Development 1995;121:439-51. 